\title{
Research on the vertical transfer process of Cu in Jiaozhou Bay
}

\author{
Dongfang Yang ${ }^{1,2,3, a}$, Fengyou Wang ${ }^{1,2, b, c}$, Sixi Zhu ${ }^{1,2}$, Yunjie Wu ${ }^{1,2}$ and \\ Xiuqin Yang ${ }^{1,2}$ \\ ${ }^{1}$ Research Center for Karst Wetland Ecology, Guizhou Minzu University, Guizhou Guiyang \\ 550025, China \\ ${ }^{2}$ College of Chemistry and Environmental Science, Guizhou Minzu University, Guizhou Guiyang \\ 550025, China \\ ${ }^{3}$ North China Sea Environmental Monitoring Center, SOA, Qingdao 266033, China \\ adfyang_dfyang@126.com; ${ }^{b}$ Corresponding author; 'wangfy2001@yahoo.com.cn
}

Keywords: Cu; Vertical distributions; Seasonal variations; Influences; Jiaozhou Bay.

Abstract. Based on the investigation data on $\mathrm{Cu}$ in surface and bottom waters in the bay mouth of Jiaozhou Bay in 1983, this paper analyzed the seasonal variations, vertical variations and horizontal distributions of $\mathrm{Cu} . \mathrm{Cu}$ contents in surface waters in the bay mouth of Jiaozhou Bay in May, September and October 1983 were ranged from 2.47-20.60 $\mu \mathrm{g} \mathrm{L}^{-1}, 1.28-4.86 \mu \mathrm{g} \mathrm{L}^{-1}$ and $0.77-2.28$ $\mu \mathrm{g} \mathrm{L}^{-1}$, and were in order of spring > summer >autumn; while for bottom waters were ranged from 0.86-3.95 $\mu \mathrm{g} \quad \mathrm{L}^{-1}, \quad 1.31-1.90 \mu \mathrm{g} \quad \mathrm{L}^{-1}$ and $0.24-2.00 \mu \mathrm{g} \quad \mathrm{L}^{-1}$, and were in order of spring >autumn >summer. The horizontal distributions of $\mathrm{Cu}$ in surface and bottom waters were consistent in May and October, while in September were reverse. At Spatial scale, Cu contents in both surface and bottom waters were tending to be decreasing. Once the input of the sources were stop, $\mathrm{Cu}$ contents in surface waters were increasing, yet in bottom waters were still decreasing. As time pass by, $\mathrm{Cu}$ contents in bottom waters were increasing along with the increasing of $\mathrm{Cu}$ contents in surface waters.

\section{Introduction}

$\mathrm{Cu}$ pollution is one of the world wide environmental issues due to the excess cupric ions is harmful to marine ecosystem and finally to human health. Jiaozhou Bay is a semi-closed bay located in the south of Shandong Peninsula, eastern China. Previous studies showed that this bay had been polluted by $\mathrm{Cu}$ [1-2]. Hence, it is necessary to understand the vertical distributions and seasonal variations of $\mathrm{Cu}$. This paper analyzed the seasonal variations, spatial distributions of $\mathrm{Cu}$ based on the investigation data on $\mathrm{Cu}$ in both surface and bottom waters in the bay mouth of Jiaozhou Bay. The aim of this paper was to provide basis for vertical sedimentation process and horizontal transfer process of $\mathrm{Cu}$, which were essential to pollution control and environmental remediation.

\section{Materials and method}

Jiaozhou Bay $\left(35^{\circ} 55^{\prime}-36^{\circ} 18^{\prime} \mathrm{N}, 120^{\circ} 04^{\prime}-120^{\circ} 23^{\prime} \mathrm{E}\right)$ is located in the south of Shandong Peninsula, eastern China. The area and and average water depth are $460 \mathrm{~km}^{2}$ and $7 \mathrm{~m}$, respectively, yet the bay mouth is only $2.5 \mathrm{~km}$ (Fig. 1). This bay is surrounding by cities of Qingdao, Jiaozhou and Jiaonan in the east, north and south, and is connected with the Yellow Sea in the south. There are more than ten inflow rivers such as Loushan River, Licun River and Haibo River, all of which are seasonal rivers [3-4]. 
The investigation on As in five sampling sites (H34, H35, H36, H37 and H82) in Jiaozhou Bay waters was conducted by North China Sea Environmental Monitoring Center in May, September and October 1983 (Fig. 1). The investigation and measurement of $\mathrm{Cu}$ were following by National Specification for Marine Monitoring [6]. We defined May, September and October as spring, summer and autumn, respectively.

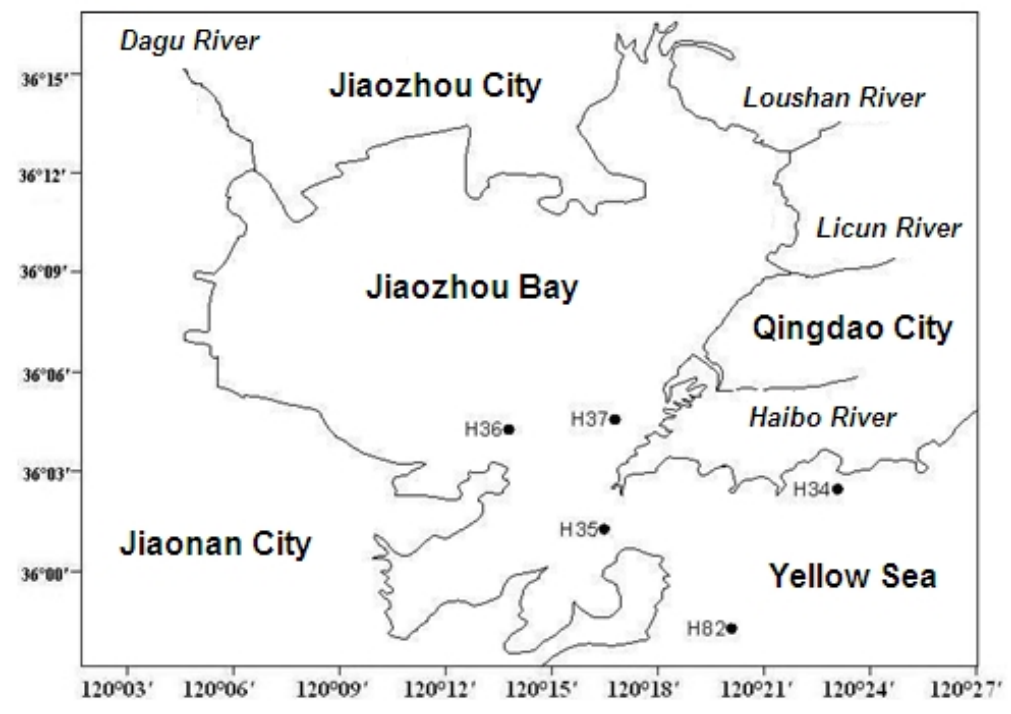

Fig.1 Geographic location and sampling sites of Jiaozhou Bay

\section{Results and discussion}

Seasonal variations of $\mathrm{Cu}$. $\mathrm{Cu}$ contents in surface waters in the bay mouth of Jiaozhou Bay in May, September and October 1983 were ranged from 2.47-20.60 $\mu \mathrm{g} \mathrm{L}^{-1}, 1.28-4.86 \mu \mathrm{g} \mathrm{L}^{-1}$ and $0.77-2.28 \mu \mathrm{g} \mathrm{L}^{-1}$, respectively, and were ranged from $0.77-2.60 \mu \mathrm{g} \mathrm{L}^{-1}$ in the whole year. $\mathrm{Cu}$ contents in surface waters were in order of spring > summer > autumn. Cu contents in bottom waters in the bay mouth of Jiaozhou Bay in May, September and October 1983 were ranged from 0.86-3.95 $\mu \mathrm{g} \mathrm{L}^{-1}, 1.31-1.90 \mu \mathrm{g} \mathrm{L}^{-1}$ and $0.24-2.00 \mu \mathrm{g} \mathrm{L}^{-1}$, respectively, and were ranged from $0.24-3.95 \mu \mathrm{g} \mathrm{L}^{-1}$ in the whole year. $\mathrm{Cu}$ contents in surface waters were in order of spring >autumn >summer.

The major sources of $\mathrm{Cu}$ in spring in Jiaozhou Bay were overland runoff, stream flow, and marine current. The source strengths of the marine current were relative high in spring, so the $\mathrm{Cu}$ contents in surface waters were highest in spring. Overland runoff and stream flow were the major $\mathrm{Cu}$ sources in summer, yet the source strengths were relative low, hence the $\mathrm{Cu}$ contents in summer in surface waters were relative low. Stream flow were the major $\mathrm{Cu}$ sources in autumn, yet the source strengths were relative low, hence the $\mathrm{Cu}$ contents in autumn in surface waters were lowest. $\mathrm{Cu}$ contents in bottom waters were mainly determined by which in surface waters, and there were sedimentation and accumulation processes in the waters by means of vertical water's effect [6]. Therefore, $\mathrm{Cu}$ contents in surface waters in spring were also highest. Since there were sedimentation and accumulation processes in the waters, a big part of $\mathrm{Cu}$ was settling and accumulating in bottom waters. Hence, $\mathrm{Cu}$ contents in autumn in bottom waters were high than in summer.

Horizontal transfer process of As. The five sampling sites were located in the inner side (H36 and H37), middle (H35) and out side (H34 and H82) of the bay mouth. In surface waters in May, Cu contents were decreasing from the inner side $\left(9.48 \mu \mathrm{g} \mathrm{L}^{-1}\right)$ to the out side $2.94\left(\mu \mathrm{g} \mathrm{L}^{-1}\right)$, while in bottom waters were also decreasing from the inner side $\left(3.88 \mu \mathrm{g} \mathrm{L}^{-1}\right)$ to the out side $\left(2.23 \mu \mathrm{g} \mathrm{L}{ }^{-1}\right)$. In surface waters in September, $\mathrm{Cu}$ 
contents were increasing from the inner side $\left(1.28 \mu \mathrm{g} \mathrm{\textrm {L } ^ { - 1 }}\right)$ to the out side $\left(4.86 \mu \mathrm{g} \mathrm{L}^{-1}\right)$, yet in bottom waters were decreasing from the inner side $\left(1.90 \mu \mathrm{g} \mathrm{L}^{-1}\right)$ to the out side $\left(1.59 \mu \mathrm{g} \mathrm{L}^{-1}\right)$. In surface waters in October, $\mathrm{Cu}$ contents were increasing from the inner side $\left(1.40 \mu \mathrm{g} \mathrm{L}^{-1}\right)$ to the out side $\left(2.00 \mu \mathrm{g} \mathrm{L}^{-1}\right)$, and in bottom waters were also increasing from the inner side $\left(1.45 \mu \mathrm{g} \mathrm{L}^{-1}\right)$ to the out side $\left(1.78 \mu \mathrm{g} \mathrm{L}^{-1}\right)$. The horizontal distributions of $\mathrm{Cu}$ in surface and bottom waters were consistent in May and October, while in September were reverse.

By means of the vertical waters's effect [6], As contents were changing a lot after pass through the water body. The growth and reproduction of marine plankton were increasing in spring and reach the climax in summer [4], and a large amount of colloid was generated in the surface of the suspended particulate matters. Hence, the absorption and sedimentation of As in waters were also increasing [2]. The major sources of $\mathrm{Cu}$ in May were marine current whose source strengths were very high, and the horizontal distributions of $\mathrm{Cu}$ contents were tend to be consistent due to the sedimentation of $\mathrm{Cu}$. The major sources of $\mathrm{Cu}$ in September were overland runoff and stream flow, whose source strengths were relative low. Although the distributions of $\mathrm{Cu}$ in surface waters were changed in September, the distributions of $\mathrm{Cu}$ in bottom waters were not changed and were same as in before. Since a big part of $\mathrm{Cu}$ was transferred to bottom waters by means of sedimentation and accumulation in autumn, the horizontal distributions of $\mathrm{Cu}$ in surface and bottom waters were tend to be consistent.

Vertical transfer process of $\mathrm{Cu}$. In order to reveal the vertical variations of $\mathrm{Cu}, \mathrm{Cu}$ contents in surface waters in the five sampling sites were subtracted by which in bottom waters, and the results were listed in Table 1. The differences in May, September and October were -0.53-16.65 $\mu \mathrm{g} \mathrm{L}^{-1},-0.62-3.27 \mu \mathrm{g} \mathrm{L}^{-1}$ and -1.23-1.74 $\mu \mathrm{g} \mathrm{L}^{-1}$. In generally, $\mathrm{Cu}$ contents in surface waters and bottom waters were closed, and $\mathrm{Cu}$ contents in bottom waters were increasing/decreasing along with the increasing/decreasing of which in surface waters.

Table 1 The minus of the As contents between the surface and bottom layers

in the Jiaozhou bay mouth waters

\begin{tabular}{cccccc}
\hline & H36 & H37 & H35 & H34 & H82 \\
\hline May & Negative & Positive & Positive & Positive & Positive \\
September & Positive & Negative & Positive & Positive & Positive \\
October & Negative & Negative & Positive & Positive & Positive \\
\hline
\end{tabular}

Once were input to the bay by overland runoff and stream flow, $\mathrm{Cu}$ was originally arrived the surface waters, and then was transferred to bottom waters rapidly and continuously. The source strengths of marine current were relative high in May, hence the $\mathrm{Cu}$ contents in waters outside the bay mouth, in the bay mouth and in the southwest inside the bay mouth were higher in surface than in bottom waters. $\mathrm{Cu}$ contents were higher in bottom waters than in surface waters in the northeast insider the bay mouth. Overland runoff and stream flow were the major sources of $\mathrm{Cu}$ in September; hence $\mathrm{Cu}$ contents in surface waters were relative high in waters in a big part of the bay, except in the southwest inside the bay mouth. Stream flow were the major Cu sources in autumn, yet a big part of $\mathrm{Cu}$ was transferred to the bottom waters in the bay, hence $\mathrm{Cu}$ contents in bottom waters in the northeast and southwest inside the bay mouth were higher than in surface waters. However, $\mathrm{Cu}$ contents in bottom waters were lower in bottom waters than in surface waters in the bay mouth and waters outside the bay mouth due to the water exchange was very strong in these areas. In generally, the vertical transfer processes of $\mathrm{Cu}$ in Jiaozhou Bay were mainly determined by the pollution sources and water exchange, as well as the homogeneity of marine waters [8]. 


\section{Conclusion}

$\mathrm{Cu}$ contents in surface waters in the bay mouth of Jiaozhou Bay in May, September and October 1983 were ranged from 2.47-20.60 $\mu \mathrm{g} \mathrm{L}^{-1}, 1.28-4.86 \mu \mathrm{g} \mathrm{L}^{-1}$ and 0.77-2.28 $\mu \mathrm{g} \mathrm{L}^{-1}$, and were in order of spring > summer >autumn; while for bottom waters were ranged from $0.86-3.95 \mu \mathrm{g} \mathrm{L}^{-1}, 1.31-1.90 \mu \mathrm{g} \mathrm{L}^{-1}$ and 0.24-2.00 $\mu \mathrm{g} \mathrm{L}^{-1}$, and were in order of spring >autumn >summer. The horizontal distributions of $\mathrm{Cu}$ in surface and bottom waters were consistent in May and October, while in September were reverse. At Spatial scale, $\mathrm{Cu}$ contents in both surface and bottom waters were tending to be decreasing. Once the input of the sources were stop, $\mathrm{Cu}$ contents in surface waters were increasing, yet in bottom waters were still decreasing. As time pass by, $\mathrm{Cu}$ contents in bottom waters were increasing along with the increasing of $\mathrm{Cu}$ contents in surface waters.

\section{Acknowledgement}

This research was sponsored by Doctoral Degree Construction Library of Guizhou Nationalities University, Education Ministry's New Century Excellent Talents Supporting Plan (NCET-12-0659), Education Ministry's New Century Excellent Talents Supporting Plan (NCET-12-0659), Project of Outstanding Technological Educators of Governor of Guizhou ([2012]71), Project of Low Carbon Technology Plan of Guiyang (2012205]), Project of Science and Technology Foundation of Guiyang (LKM[2012]05), Special Research Projects of High Level Talents of Guizhou Province (TZJF-2011-44), the China National Natural Science Foundation (31560107) and Research Projects of Guizhou Nationalities University ([2014]02), Research Projects of Guizhou Province Ministry of Education (KY [2014] 266), Research Projects of Guizhou Province Ministry of Science and Technology (LH [2014] 7376).

\section{Reference}

[1] Dong DF, Miao ZQ, Song WP et al.: Advanced Materials Research, Vol.1092-1093 (2015), p. 1013-1016.

[2] Yang DF, Miao ZQ, Cui WL, et al.: Advances in intelligent systems research, Vol. (2015), p. 17-20.

[3] Yang DF, Chen Y, Gao ZH, et al.: Chinese Journal of Oceanology and Limnology, Vol. 23 (2005), pp. 72-90.

[4] Yang DF, Wang F, Gao ZH, et al.: Marine Science, Vol. 28 (2004), p. 71-74. (in Chinese)

[5] State Ocean Administration. The specification for marine monitoring: Beijing, Ocean Precess, (1991).

[6] Yang DF, Wang FY, He HZ, et al.: Proceedings of the 2015 international symposium on computers and informatics, 2015, p. 2655-2660.

[7] Yang DF, Ding ZR, Zheng L, et al.:Coastal Engineering, Vol. 30(2011), p. 66-74. (in Chinese) 